\title{
JOSÉ DE ALENCAR E OS EMBATES EM TORNO DA PROPRIEDADE LITERÁRIA NO RIO DE JANEIRO (1856-1875)
}

José de Alencar and the clashes around literary property in Rio de Janeiro (1856-1875)

José de Alencar y los embates en torno a la propiedad literaria en Río de Janeiro (1856-1875)

RODRIGO CAMARGO DE GODOI

http://dx.doi.org/10.1590/s2178-14942017000300004

Rodrigo Camargo de Godoi é mestre em Teoria e História Literária e doutor em História pela Universidade Estadual de Campinas (UNICAMP). Este artigo recebeu apoio da Fundação de Amparo à Pesquisa do Estado de São Paulo (FAPESP) (rcgodoi@unicamp.br).

Artigo recebido em 30 de maio e aprovado para publicação em 30 de agosto de 2017. 


\title{
Resumo
}

0 artigo analisa as discussões no parlamento imperial de três projetos de lei destinados a proteger a propriedade literária no Brasil. Em comum, os projetos enfatizavam a importância da literatura dramática para os autores, a qual, contraditoriamente, convertera-se em fonte de lucros para empresários teatrais e editores. Destaca-se o projeto apresentado pelo deputado, jurista e romancista José de Alencar em 1875. A partir do episódio envolvendo a adaptação de seu romance $O$ Guarani para os palcos, Alencar formulou as bases de uma legislação que visava reconhecer a propriedade literária como expressão do trabalho intelectual materializado no impresso.

PalaVras-CHAVE: teatro; trabalho intelectual; propriedade literária.

\begin{abstract}
The paper analyzes the Brazilian imperial parliament discussion on three bills designed to protect literary property. The projects emphasized the importance for the authors of their theater plays, which, in contradiction, became a source of profits for theater entrepreneurs and publishers. The analysis underlines the project presented by the congressman, jurist and novelist José de Alencar in 1875. From the adaptation of his novel 0 Guarani to be played on stage, Alencar framed a legislation in order to recognize literary property as an expression of intellectual labor materialized by the press.
\end{abstract}

KeYwords: theater; intellectual labor; literary property.

\section{RESUMEN}

El artículo analiza las discusiones en el parlamento imperial de tres proyectos de ley destinados a proteger la propiedad literaria en Brasil. En común, los proyectos enfatizan la importancia para los autores de la literatura dramática, que, contradictoriamente, se convertía en fuente de beneficios para empresarios teatrales y editores. En este sentido, se destaca el proyecto presentado por el diputado, jurista y novelista José de Alencar en 1875. A partir de la adaptación de su novela El Guaranípara los escenarios, Alencar formuló las bases de una legislación que pretendía reconocer la propiedad literaria como expresión del trabajo intelectual materializado en el impreso.

Palabras CLAVE: teatro; trabajo intelectual; propiedad literaria. 


\section{INTRODUÇÃO}

S e partirmos do exemplo de Goethe, a relação do intelectual com a caricatura pode ter $\checkmark$ sido problemática no início do século XIX. Refratário às ilustrações de William Hogarth e seus seguidores, Goethe via na caricatura uma subversão estética, o triunfo do disforme sobre a forma, e uma subversão política, tendo em vista o potencial dos desenhos sobre a plebe. Foi apenas a partir das tirinhas cômicas aparentemente amenas do Rodolphe Töpffer que 0 autor do Fausto passou a olhar com certa benevolência para um gênero editorial já popular em seu tempo (Kunzle, 1985). Como demonstram os estudos pioneiros de Grand-Carteret (1907) sobre Émile Zola, não demorou muito para que poetas e romancistas se tornassem objeto dos caricaturistas. Em contrapartida, a influência dos cartunistas pode ter sido decisiva para a criação literária oitocentista (Sandras-Fraysse, 2014).

As caricaturas representando intelectuais serão muito importantes neste artigo que analisa principalmente os embates de José de Alencar em torno da defesa da propriedade literária e do trabalho intelectual no Rio de Janeiro do século XIX. Comecemos, pois, por uma delas, publicada no jornal 0 Mosquito em setembro de 1876:

Figura 1: $O$ Mosquito, 9 set. 1876, p. 5.

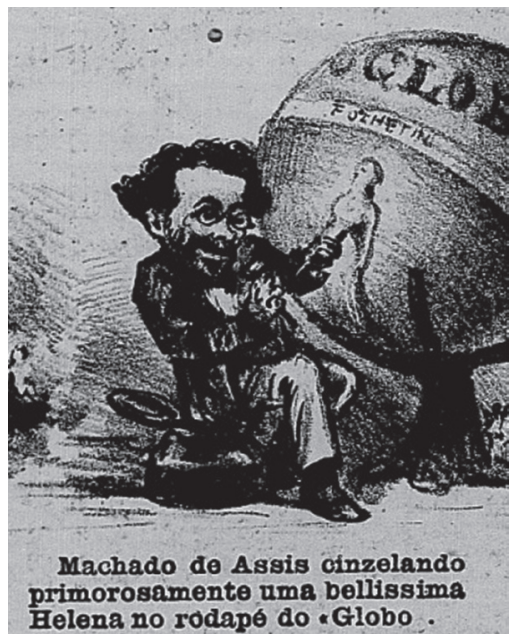


O caricaturado era o jovem Machado de Assis, representado "cinzelando" sua "belíssima Helena" nos folhetins de 0 Globo. 0 desenho ecoava um poema famoso de Victor Hugo (1856: 77-78) que anos mais tarde, em 1886, reapareceria na epígrafe de "Profissão de fé", poema de Olavo Bilac (1902: 11-16):

Nous sommes frères: la fleur

Par deux arts peut être faite.

Le poète est ciseleur;

Le ciseleur est poète.

Poètes ou ciseleurs,

Par nous l'esprit se révèle.

[...]

Tous les penseurs, sans chercher

Qui finit ou qui commence,

Sculptent le même rocher,

Ce rocher, c'est l'art immense.

Subjacente tanto ao desenho quanto ao poema habita a ideia do escritor como indivíduo que trabalha com as mãos. Munido do cinzel, ele esculpe o pensamento dando-lhe contornos físicos, materialidade. No caso de Machado, desde agosto de 1876 Helena era esculpida nos rodapés das primeiras páginas de 0 Globo.

0 romance foi publicado em livro pelo editor Baptiste-Louis Garnier no início de outubro. Cumprido à risca, o contrato fora assinado meses antes, em fins de abril de 1876. Na ocasião ficou acordado que Joaquim Maria Machado de Assis vendia por 600 mil réis ao editor Garnier um romance a princípio intitulado Helena do Vale que, depois de publicado em O Globo, seria impresso em livro com uma tiragem de 1.500 exemplares. 0 contrato estabelecia também que Machado não podia reimprimir o romance antes que a primeira edição estivesse esgotada. ${ }^{2}$ Em síntese, o documento representava a transferência de propriedade da

\footnotetext{
1 "Somos irmãos: a flor/ Por duas artes pode ser feita./ 0 poeta é gravador;/ 0 gravador é poeta./ Poetas ou gravadores,I Por nós o espírito se revela./ [...]/ Todos os pensadores, sem indagar/ Quem termina ou quem começa,/ Esculpem a mesma pedra; /Essa rocha é a arte imensa". Agradeço a Camila Loureiro Dias pela revisão da tradução.

${ }^{2}$ Assis, Machado de. Contrato celebrado entre Joaquim Maria Machado de Assis e o editor B. L. Garnier para a pa edição da obra Helena do Vale. Consta o recibo da importância paga por esse contrato. Rio de Janeiro, 29 abr. 1876. Biblioteca Nacional do Rio de Janeiro, Manuscritos, I-7, 9, 4.
} 
primeira edição de Helena, prática cartorial comum, por exemplo, nas escrituras de compra e venda de escravos a partir de $1860 .^{3}$

Mas diferentemente dos cativos, a natureza da propriedade literária, que na ocasião Machado transferia a Garnier, baseava-se em determinada noção de trabalho muito cara a juristas e intelectuais no século XIX. Porém, com exceção do artigo 261 do Código Crimina/ de 1830 e até a promulgação da Lei 496 de 10 de agosto de 1898, não havia dispositivo legal no país que garantisse a propriedade literária em sua plenitude.

Todavia, nesse ínterim, três projetos de lei foram apresentados à Câmara dos Deputados na Corte com o objetivo de assegurar a propriedade dos autores. 0 teatro mereceu destaque em todos eles. Na medida em que transcendia o texto como fenômeno sociocultural, a literatura dramática distinguia-se dos demais gêneros literários por seu potencial lucrativo. Ao contrário do romance e da poesia, o teatro convertera-se em um bom negócio, tanto para os empresários da cena como para empresários do livro. A recente historiografia do teatro brasileiro tem destacado a ação decisiva de "capitalistas" como Joaquim Heliodoro Gomes dos Santos, à testa da renovação empreendida pelo Teatro Ginásio Dramático do Rio de Janeiro precisamente na década de 1850, quando dois dos três projetos foram apresentados. Nas últimas décadas do século XIX, entravam em cena outros empresários teatrais de renome como Jacinto Heller, Braga Júnior, Sousa Bastos e Ismênia dos Santos (Souza, 2002; Mencarelli, 2003). A edição de textos dramáticos, por sua vez, alegrou as algibeiras de muitos editores do século XIX, como Paula Brito, no Rio de Janeiro, e Michel Lévy, em Paris. Isso porque os espectadores faziam questão de adquirir os exemplares das peças de sucesso (Mollier, 2007; Godoi, 2016).

Na maioria dos casos os lucros provenientes dessa dupla performance do texto dramático ficavam nas mãos de empresários e editores. Eram, portanto, consideráveis as chances do autor de uma comédia, drama ou revista de ano de sucesso ficar a ver navios. Certamente não foi por acaso que debates em torno da propriedade literária empreendidos na Câmara dos Deputados e na imprensa do Rio de Janeiro necessariamente atravessaram os palcos.

\section{I - TEATRO E PROPRIEDADE LITERÁRIA (1856-1857)}

L presentado na Câmara em agosto de 1856, o projeto do deputado cearense Aprígio
Justiniano da Silva Guimarães destacava-se em dois pontos. Primeiramente por prever a celebração de tratados com o Reino de Portugal, tendo-se em vista "a facilidade dos danos

\footnotetext{
${ }^{3}$ Em 1860, a Lei n. 1.114 exigiu o registro público das transações de compra e venda de cativos (Slenes, 1986: 117). 0 Decreto 4.533 de 17 de abril de 1869, que regulamentava a arrecadação de impostos de transmissão de propriedade, isentava "os atos de transmissão de propriedade literária e artística" (Art. 4, § 3ํ).
} 
da contrafação resultante da identidade da língua dos dous países" (art. 8). Em segundo lugar, por ampliar o conceito de "propriedade intelectual", considerando-o "toda sorte de produção nas ciências, letras e belas artes" (art. 1, § 10). 0 projeto previa multas e confiscos sobre missivas, sermões, preleções e discursos impressos sem a autorização dos autores em livros ou periódicos (art. 3). A propriedade intelectual seria vitalícia e transmissível aos herdeiros dos autores pelo prazo de 30 anos (art. 1). Em relação aos teatros, o projeto estabelecia que "todo empresário de teatro ou associação de atores que representar drama composto ou traduzido por escritor brasileiro, sem sua prévia licença, sofrerá em favor deste e por cada representação uma multa igual à metade da receita do espetáculo, considerados todos os lugares ocupados" (art. 4).

Ao restringir a proteção aos "cidadãos brasileiros" o projeto de lei fazia eco ao artigo 261 do Código Criminal de 1830. Contudo, em face da internacionalização do mercado editorial no século XIX, o artigo era extremamente frágil neste ponto. Apesar de Aprígio Guimarães tentar oferecer uma solução ao problema da proteção de autores estrangeiros por meio de tratados e convênios, seu projeto de lei não avançava na questão. 0 projeto ficou à espera do parecer da Comissão de Justiça Criminal da Câmara, única capaz de estabelecer penalidades. E, embora a iniciativa pouco repercutisse nos jornais da Corte, um articulista anônimo de 0 Grito Nacional dizia que "o projeto do Sr. Aprígio é de um alcance que nem um telégrafo elétrico o apanharia em caminho". Mas, já desmentindo sua relevância, ele arrematava: "livre da chacota, se continuar assim, podemos rezar pela alma do Sr. Aprígio nos bancos da representação nacional". 4

Um ano depois, Bernardo Avelino Gavião Peixoto, deputado paulista, retomou a matéria. Durante a campanha eleitoral, sua atuação como orador e magistrado foi destacada, bem como sua nomeação para chefe de polícia no Rio Grande do Sul. ${ }^{5}$ Considerando que no século XIX e alhures teatro era assunto policial, tal nomeação torna-se sugestiva das preocupações de Gavião Peixoto com os palcos. ${ }^{6} 0$ longo discurso do deputado sobre teatros e propriedade literária causou frisson na Câmara no dia 21 de agosto de 1857. 0 estenógrafo registrou 0 "movimento geral de atenção" no instante em que ele tomou a palavra a fim de fundamentar seus três projetos de lei. 0 primeiro taxando os entretenimentos, o segundo regulando a atividade teatral a fim de proteger os autores dramáticos e o terceiro com o objetivo de garantir

\footnotetext{
4 "A garantia literária e o Sr. Aprígio", O Grito Nacional, 30 ago. 1856, p. 2.

5 "A candidatura do Dr. Bernardo Avelino Gavião Peixoto pelo distrito eleitoral de Santos", Correio da Tarde, 31 out. 1856, p. 3. ${ }^{6}$ Em 1855, o chefe de polícia da Corte interveio pessoalmente a fim de conter manifestações dos espectadores, principalmente as pateadas no Teatro Lírico. "A proibição das pateadas nos teatros", Marmota Fluminense, 9 fev. 1855, p. 1.
} 
a propriedade literária. 0 estenógrafo também registrou todos os "apoiados" que o deputado recebeu logo no preâmbulo do discurso no qual justificava a relevância dos projetos:

A literatura, Senhor presidente, por sua importância e serviços, está de há muito considerada como uma instituição tão digna de cuidados de um país civilizado, como todas as outras que compõem sua sociedade (Apoiados). Prestar a ela toda a atenção, dar-lhe impulso, promover o seu desenvolvimento, passou já de um favor concedido pelos parlamentos ilustrados, para uma obrigação rigorosa, para um dever imperioso, cujo esquecimento ou desprezo deve ser estigmatizado com todas as forças (Apoiados). ${ }^{7}$

Mas, se a literatura era considerada uma instituição nacional, o teatro merecia especial atenção:

E sendo o teatro, Senhor presidente, geralmente compreendido como a fórmula literária mais do gosto do público, mais consentânea com a natureza dos povos, e por isso mesmo a mais influente em seu espírito, a que mais facilmente atua em seu modo de existir; sendo igualmente verdade que os costumes de um povo modelam-se e formam-se segundo suas instituições; parece-me evidente que empregar todos os meios possíveis para a boa organização dos teatros é menos uma superabundância de cuidado que um rigoroso dever. Por isso no projeto que apresento sobre esta matéria obrigo as empresas e direções teatrais a ter uma escrituração mercantil registrada no tribunal do comércio, e a outras obrigações mais, em benefício dos escritores dramáticos, e animar as produções brasileiras. ${ }^{8}$

Desde meados dos 1840, o romance brasileiro paulatinamente adquiria relevância, sobretudo a partir das incursões de Teixeira e Sousa e de Joaquim Manuel de Macedo no gênero. Mas essa "fórmula literária" emplacaria a partir da década de 1860. No momento em que Gavião Peixoto redigia seu projeto de lei, a acolhida do realismo teatral pelos literatos do Rio convertia os palcos na instância legitimadora da atividade literária. Conscientes da influência do teatro sobre o espírito do público, toda uma geração de jovens escritores - entre os quais Machado de Assis, José de Alencar, Quintino Bocaiuva - almejou a consagração pelo tablado (Faria, 1993; Souza, 2002). Assim, a imagem de Pinheiro Guimarães (Figura 2) sendo ovacionado no Teatro Ginásio após a encenação de sua peça História de uma moça rica torna-se síntese tanto das ambições de seus confrades como das preocupações de Gavião Peixoto.

\footnotetext{
${ }^{7}$ Anais da Câmara dos Deputados, Sessão de 21 de agosto de 1857, p. 45. Ver também: "Câmara dos Srs. Deputados: Discurso do Sr. Gavião Peixoto proferido na sessão de 21 de Agosto", Jornal do Commercio, 26 ago. 1857, p. 1.

${ }^{8}$ Idem, ibidem.
} 
Figura 2: "História de uma moça rica: último quadro depois de acabar a peça".

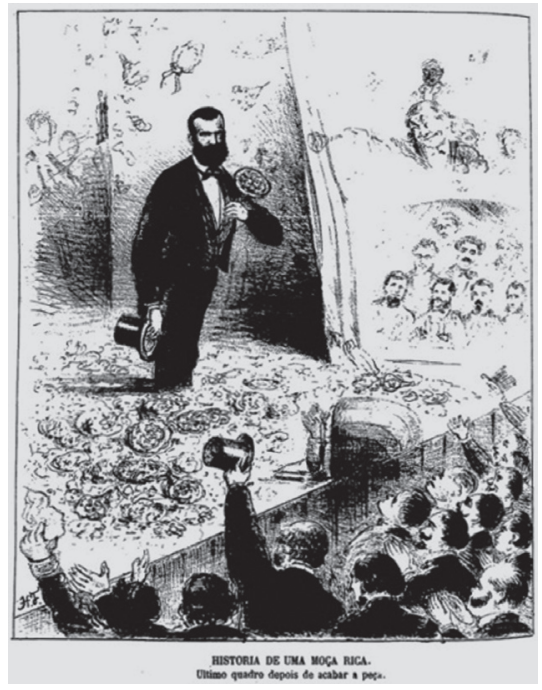

Fonte: Semana Illustrada, n. 44, 13 out. 1861, p. 352.

Com efeito, o diagnóstico do deputado era preciso: "o teatro entre nós não passa por hora de um negócio. 0 espírito mercantil que existe neste século tanto tem progredido, já avassalou até o teatro, até as letras. (Apoiados)." Para Gavião Peixoto, o Conservatório Dramático Brasileiro, órgão oficial de censura teatral na Corte, nada fazia no sentido de reverter o quadro. Destinar o produto da terceira representação de uma peça para o pagamento de seu autor, conforme a Regulamentação dos Teatros da Corte publicada 1854, também pouco ajudava. Conforme ilustrava o deputado, esse arranjo não passava de uma mal disfarçada pilhagem. 0 argumento central de Gavião Peixoto era o reconhecimento da atividade literária como um trabalho:

A inteligência auxiliada pelo trabalho é um capital tão digno de um juro, como qualquer capital monetário que se cativa a uma empresa. E por que razão será depreciada ou suplantada em serviço de um outro capital, às vezes menos trabalhoso e moral?

Não, Senhor presidente, assim não deve ser. Há homens, e os mais serviçais que vieram a esse mundo, tendo por única riqueza, por único elemento de sua subsistência - o talento. A esses, pois, a sua recompensa, a sua compensação. Se seu trabalho é digno e aplaudido, ganhe ele na proporção do sócio que se aliou para o fim de seus mútuos interesses. Se a peça representada é boa e do agrado do público, tenha ele em cada noite de sua representação uma parte nos lucros que dela retira a empresa do teatro. ${ }^{9}$

\footnotetext{
${ }^{9}$ Anais da Câmara dos Deputados, Sessão de 21 de agosto de 1857, p. 46.
} 
Desamparado, o intelectual estaria fadado à penúria, sendo seu único legado "a lembrança gloriosa de seu nome com a miséria por sócia". Destino, por exemplo, do mencionado Teixeira e Sousa, em cujo necrológio publicado na Revista Popular lia-se: "era um grande talento que nascera pobre, que se elevara por esforço próprio, que brilhara na maior adversidade, como as plantas odoríferas, que tanto mais se maceram, quanto mais recendem". Mas, a despeito do reconhecido mérito de suas obras, ele "morreu pobre". ${ }^{10}$

Gavião Peixoto entendia que tais dramas poderiam ser evitados por meio de leis que protegessem os autores. Assim, o primeiro projeto estabelecia um imposto de $5 \%$ sobre "todo e qualquer gênero de divertimento" (art. 1), sendo o montante arrecadado destinado ao estabelecimento de uma caixa de socorro público, a fim de "minorar os sofrimentos das classes do país". Muitos intelectuais empobrecidos poderiam se valer de tais recursos. 0 segundo projeto de lei versava exclusivamente sobre os teatros. Se promulgada, a lei previa que toda empresa teatral deveria manter livros contábeis registrados no Tribunal do Comércio (art. 1 §1), bem como escriturar todas as peças de seu repertório (art. 1 §2). Anualmente, além de promover um concurso dramático (art. 1 §3), as companhias seriam obrigadas a representar originais brasileiros (art. 1 §6). Descumpridas as disposições, as multas eram de 1 a 3 contos de réis.

Gavião Peixoto almejava blindar o autor dramático contra a suposta ganância dos empresários teatrais. Nenhuma peça, original ou imitação, poderia ser montada "sem o consentimento formal ou por escrito de seu autor ou tradutor" (art. 2). A remuneração do autor dramático obedecia a uma curiosa hierarquia de gêneros. Por exemplo, o autor brasileiro ou estrangeiro de um drama em 5 atos em "língua nacional" teria acesso a todos os ensaios, assim como o direito de "dirigir a representação". Na noite de estreia, este mesmo autor receberia $20 \%$ da receita bruta do espetáculo, além de seis cadeiras na primeira classe. Nas noites subsequentes, receberia $10 \%$ da receita bruta, bem como entrada franca a cada uma delas (art. 2 §1; art. 8-9). Embora pudesse vender sua obra a uma companhia, o autor ainda manteria o direito de exigir sua montagem, intervindo, inclusive, na distribuição dos papéis entre atores e atrizes (art. 2 §8-9). Por outro lado, independentemente do contrato assinado com determinada companhia, os autores gozariam de total liberdade para contratar com 0 editor de sua preferência a impressão das peças. Salvo acordos já firmados, eles também estavam livres para negociar a representação de suas obras em qualquer teatro do Império (art. 4). Garantias extensivas aos compositores musicais (art. 11).

0 terceiro projeto garantia "aos autores brasileiros a propriedade de suas obras vitaliciamente" (art. 1). 0 entendimento de "obras" era amplo, abrangendo "toda a sorte de

10 "Crônica da Quinzena", Revista Popular, T. XII, p. 380. 
produção em ciências, letras e belas artes"; assim, contrafator era "todo aquele que introduzir qualquer escrito, composição musical, pintura ou qualquer produção intelectual sem licença do autor ou tradutor, ou fora da letra do contrato estipulado por ele como o editor ou outra qualquer pessoa" (art. 2 §1). 0 mesmo valia para obras de brasileiros reproduzidas de modo indevido no exterior, para a impressão não autorizada de cartas que versavam sobre temas literários e científicos, bem como de discursos e prelações estenografadas. As penas incidiam em multas, confiscos de exemplares e prisão de 1 a 6 meses (art. 2 §2-10). Gavião Peixoto procurava resolver o problema dos autores estrangeiros estendendo a eles as garantias do projeto (art. 1 §2).

Além da necessidade do contrato registrado (art. 5), o projeto de lei firmava a importância do depósito legal para o reconhecimento da propriedade literária por meio da remessa compulsória de exemplares da obra à Biblioteca Pública do Rio de Janeiro e aos arquivos provinciais. 0 depósito era a condição para se levar adiante qualquer ação judicial a fim de se reconhecer ou contestar a propriedade intelectual (art. 9). No caso da imprensa, os artigos ou séries de textos, originais ou traduzidos, pertenceriam aos jornais e periódicos. Reimpressões, no entanto, poderiam incorrer em multa de 50 mil réis por artigo em favor dos autores ou tradutores (art. 4).

Em maio de 1858, Gavião Peixoto requereu que seu projeto de lei sobre os teatros fosse remetido à Comissão de Constituição da Câmara, onde deveria aguardar parecer. 0 requerimento foi deferido após derrubar a proposta do deputado Viriato, que, por sua vez, queria destinar o projeto às comissões de Instrução Pública e Justiça Civil. Quanto ao projeto sobre propriedade literária, o deputado Villela Tavares defendeu com sucesso a conveniência das comissões de Constituição e Justiça Criminal o analisarem em conjunto com o texto de Aprígio Guimarães. ${ }^{11}$ 0 parecer sobre a matéria saiu em julho de 1858. Salvo pequenas exceções, os dois projetos de lei foram considerados quase idênticos, sendo que o projeto do deputado cearense destacava-se por defender a celebração de acordos entre Brasil e Portugal. Recomendou-se então que se levassem adiante as discussões do projeto de Aprígio Guimarães. ${ }^{12}$

Mal disfarçando o contentamento, em 1859 Aprígio publicou um opúsculo sobre o assunto no Recife. 0 então ex-deputado discutia os pontos de convergência e divergência entre seu projeto de lei e o de Gavião Peixoto, sublinhando a importância de um acordo literário entre os países de língua portuguesa. Banida a contrafação, o Brasil se converteria em um

\footnotetext{
${ }^{11}$ Anais da Câmara dos Deputados, Sessão de 30 de maio de 1858, p. 46. "Câmara dos deputados", Jornal do Commercio, 22 mai. 1858, p. 2.

12 Anais da Câmara dos Deputados, Sessão de 17 de julho de 1858, p. 156.
} 
mercado promissor para os autores portugueses, e Portugal para os autores brasileiros. Mas, retomando a questão do trabalho letrado, Guimarães (1859) defendia que só a regulamentação da propriedade literária poderia pôr termo "ao furor atual pelos empregos públicos, mal que ataca os próprios, que poderiam ser bons produtores intelectuais". Mas os dois projetos acabaram esquecidos. Tanto que, em 1868, o comediógrafo Augusto de Castro registrava que Gavião Peixoto "pregou aos peixinhos e teve de recolher-se ao silêncio, depois de esbofar-se em vão". ${ }^{13}$ Porém o assunto seria retomado na Câmara em 1875, graças a outro deputado cearense: José de Alencar. ${ }^{14}$

\section{JOSÉ DE ALENCAR E O PROJETO DE LEI DE 1875}

$\mathrm{O}$

projeto de lei sobre a propriedade literária apresentado por José de Alencar na sessão de 7 de julho de 1875 era precedido por um longo texto intitulado "Fundamento do projeto". Nele, Alencar expunha as bases da legislação proposta, sendo sua pedra angular a equiparação da propriedade literária e artística à propriedade em geral. 0 parlamentar defendia que ambas usufruíssem das mesmas garantias, nomeadamente a transmissão hereditária, "sem limitação de tempo e sem distinção de nacionalidade" (art. 1). 0 projeto considerava autores os tradutores e copistas de obras de arte que atuassem nos parâmetros da lei (art. 10). Já em relação ao jornalismo, estipulava que os artigos que não trouxessem a rubrica "reprodução reservada" poderiam ser livremente transcritos em outros jornais e revistas, sendo proibida sua compilação em livro sem a autorização dos autores (art. 6). Certamente a partir de sua experiência como redator-chefe do Diário do Rio de Janeiro, Alencar concedia aos jornais o direito de "estenografar e publicar sem permissão qualquer discurso que seja proferido em ato público e oficial". Em contrapartida, as folhas eram obrigadas a publicar eventuais emendas e correções solicitadas pelos autores (art. 7). 0 depósito legal das obras era condição essencial para que o autor pudesse se beneficiar da lei (art. 8). ${ }^{15}$

A defesa da propriedade literária e artística desdobrava-se na defesa inconteste do trabalho intelectual. São, portanto, abundantes no "Fundamento do projeto" os trechos nos quais José de Alencar revelava-se um fervoroso defensor dos "operários da inteligência". No entanto, o reconhecimento "do pensamento vasado em livro [como] uma cousa susceptível de domínio" encontrava resistências sociais e jurídicas. No primeiro caso o argumento era

\footnotetext{
13 "Desabafo", A Vida Fluminense, 6 jul. 1868, p. 8.

14 J. M. Vaz Pinto Coelho, "Da propriedade literária no Brasil", Revista Brasileira, T. VI, out.-dez., 1880, p. 479-480.

${ }^{15}$ Anais da Câmara dos Deputados, Sessão de 7 de julho de 1875, p. 28.
} 
que produções do espírito pertenceriam à humanidade, pois "longe de ser um direito constituem um dever". Raciocínio bastante semelhante ao de certa jurisprudência que inscrevia tais produções entre as "riquezas universais" - como o ar, a luz etc. - "que não podem cair no domínio privado". José de Alencar rebatia tais ideias defendendo com unhas e dentes "a mais nobre das profissões, a do escritor", pois "não há propriedade que tenha maior cunho da individualidade do que essa que o homem tira de si, de suas faculdades, do seu trabalho". ${ }^{16}$

O projeto de lei não apresentava um artigo que tratasse de modo direito dos teatros ou da literatura dramática, a exemplo dos projetos anteriormente levados à Câmara. Entretanto, Alencar mostrava-se bastante preocupado em legislar sobre os diferentes modos de reprodução ilegal das obras, inclusive a reprodução pública por "exibição ou representação":

Art. 2‥ A reprodução pública da essência ou substância da obra literária e artística por qualquer modo ou processo, incluída a exibição ou representação, só pode ser feita pelo autor e seus sucessores, ou em virtude de cessão dos mesmos, provada por escritura pública.

Consiste a essência ou substância da obra:

1‥ No título, quando esse for da invenção do autor por sua originalidade, ou novidade da combinação.

2‥ Na forma, a qual para o livro e a música se resume na frase e estilo; e para as artes plásticas no desenho e atitude.

3‥ Na contextura e plano da obra, desde que sejam de criação própria.

Art. 3․ A reprodução pública integral ou geral de obras por qualquer modo ou processo, incluída sua exibição ou representação, sendo feita por terceiro sem consentimento do autor, nos termos do art. $2^{\circ}$, constitui crime de contrafação e será punida com as penas do furto. ${ }^{17}$

Para Alencar havia uma distinção clara entre plágio e contrafação. Ele explicava que a palavra francesa contrefaçon, que poderia ser traduzida por "simulação", foi o termo adotado pela jurisprudência para caracterizar o furto intelectual "perfeitamente caracterizado". 0 plágio, por se tratar da reprodução de trechos, podia ser considerado uma "violação menos grave, porque, além de parcial, pode ser fortuita e cometida de boa fé" ${ }^{18} 0$ que caracterizava um ou outro delito era a medida da usurpação da "essência ou substância da obra", ambas identificadas em seu título, forma e contextura. Explicando-se melhor, Alencar afirmava que 0 título era "um dos mais importantes elementos da obra e um dos traços que mais concorrem

\footnotetext{
${ }^{16}$ Idem, Ibidem.

17 Anais da Câmara dos Deputados, Sessão de 7 de julho de 1875, p. 28. Grifos meus.

${ }^{18}$ Idem, Ibidem.
} 
para individualizá-la". Conforme o parlamentar-literato, o título poderia ser geral ou especial. O primeiro era aquele já disponível pela ciência ou pelo uso, por exemplo: História do Brasil, Gramática Nacional, Ressurreição, Cromwell, entre outros. Já o título especial era inteiramente concebido pelo autor, por exemplo: Atala, Hernani, Os Lusíadas, etc. A forma assinalava "a feição, o aspecto, a maneira, a configuração exterior da obra". A individualidade do autor exprimia-se por intermédio da forma, a qual podia ser entendida por estilo. Quanto à contextura, Alencar advertia que este era um elemento de difícil análise: "sob essa denominação compreendemos o método, a disposição das diversas partes, a combinação das matérias, 0 sistema de organização da obra". Da contextura dependia a "clareza nos assuntos científicos e a beleza nos assuntos literários e artísticos". Em matéria literária ela abrangia "a divisão das partes, o método de exposição, os personagens ou caracteres, [e] o desenvolvimento das cenas", elementos que serviam para averiguar a ocorrência de plágio ou contrafação. ${ }^{19}$

0 modo como Alencar revelava-se preocupado com a "representação pública" dos seus textos enraizava o projeto de lei na experiência histórica do autor. Em 1858, sob a acusação de imoralidade, sua peça As asas de um anjo foi retirada de cartaz pela polícia após a terceira representação. Na ocasião, Alencar indispôs-se publicamente, e com boa dose de razão, com o Conservatório Dramático Brasileiro que a princípio havia considerado a peça apta para os palcos. No entanto, é interessante observar que, ao imprimir a peça, ele fez questão de estampar no volume a seguinte advertência: "Esta comédia, embora impressa, não pode ser representada sem licença do autor" (Alencar, 1860: VI). 0 volume contendo 0 demônio familiar (1858), peça de Alencar publicada dois anos antes, não trazia advertência semelhante. Isso sugere que, depois do episódio envolvendo As asas de um anjo, Alencar passou a zelar pela encenação de suas peças publicadas. ${ }^{20}$

Contudo, a "essência e substância" da legislação apresentada na Câmara dos Deputados em julho de 1875 estaria ligada de modo mais direto à atribulada adaptação do romance O Guarani para os palcos meses antes, entre fins de 1873 e meados de 1874. Em Alencar, a defesa da propriedade literária e do trabalho intelectual igualmente atravessa o teatro, a um só tempo "a fórmula literária mais do gosto do público" e "um negócio", conforme lembrava Gavião Peixoto. ${ }^{21}$

\footnotetext{
${ }^{19}$ Anais da Câmara dos Deputados, Sessão de 7 de julho de 1875, p. 30-31.

${ }^{20} 0$ volume contendo o drama Mãe igualmente advertia: "Este drama não pode ser representado sem licença do autor" (Alencar, 1862).

${ }^{21}$ Em artigo sobre o projeto de José de Alencar, Augusti (2002: 214), a partir das formulações de Chartier, apresenta interpretação diversa: "a elaboração alencariana acerca dos três elementos constitutivos e distintivos da produção intelectual pode ser remetida, com o devido cuidado, ao longo debate que se deu na Europa do Setecentos quando se tratou de estabelecer a duração do copyright".
} 


\section{A QUESTÃO GUARANI E O "SUOR DA INTELIGÊNCIA"}

1 Questão Guarani foi estudada em detalhes por João Roberto Faria (1982), especialista tação referente à polêmica, exceto as caricaturas analisadas adiante. Em 1857, o romance 0 Guarani de José de Alencar foi publicado em folhetim no Diário do Rio de Janeiro transformando-se nos anos seguintes em um fenômeno. Em dezembro de 1870 estreava no Teatro Lírico Fluminense a ópera de Carlos Gomes baseada no romance. Graças à "Hora do Brasil", programa radiofônico herdado dos tempos de Vargas, ainda hoje reconhecemos as notas iniciais do prelúdio de // Guarani. José de Alencar, no entanto, apesar de mostrar-se lisonjeado com o sucesso da ópera, entre os mais íntimos teria confessado reservas diante das alterações que 0 maestro livremente introduzira na história de Peri e Ceci (Faria, 1982: 60).

Em fins de 1873, no vácuo do sucesso da ópera, Jacinto Heller, empresário do teatro Fênix Dramática, decidiu fazer uma adaptação do romance para os palcos. No entanto, projetada para integrar o repertório do teatro musicado que então gozava de imenso sucesso na Corte, a peça seria montada a partir de O Guarani com músicas compostas por Carlos Gomes. Em suma, uma salada do romance com a ópera, dois produtos bem sucedidos no mercado fluminense de bens culturais. Heller contratou Luiz José Pereira da Silva e José Alves Visconti Coaracy para realizarem a adaptação. A correspondência de Alencar demonstra que houve conversas preliminares entre ele e Coaracy sobre as condições em que se daria a montagem da peça. Porém, já em abril de 1874, quando o Jornal do Commercio começou a divulgar os anúncios da representação, Alencar publicou no mesmo jornal uma nota acusando o roubo de sua propriedade literária. Essa nota desencadeou uma série de artigos na imprensa. Primeiramente o romancista, que acusara o Conservatório Dramático de conivência com a espoliação literária, bateu-se por dias nas colunas do Jornal do Commercio com Cardoso de Meneses, presidente da instituição (Faria, 1982: 62-78). A caricatura publicada na revista O Mosquito ilustrava bem a peleja, ou, conforme a legenda do desenho, o "dueto sobre o Guarani (Música de C. Gomes) entre os Srs. Alencarini e Cardoso de Menezini". Duo que, "longe de agradar o empresário Heller, produz-Ihe violentas cólicas! Ai meus cobres!".

Outras pessoas entraram na contenda por meio de pseudônimos, como Guaicuru e Peri, até que, já em fins de abril, Jacinto Heller e José de Alencar finalmente entraram em acordo sobre a adaptação de $O$ Guarani. Afinal, havia muito dinheiro envolvido. Em um dos artigos assinados pelo empresário sabemos que a peça já havia consumido em torno de 18 contos de réis na pintura dos cenários, guarda-roupa, contratação de artistas, coristas, entre outras despesas (Faria, 1982: 62-78). 
Figura 3: $O$ Mosquito, 25 abr. 1874, p. 4.

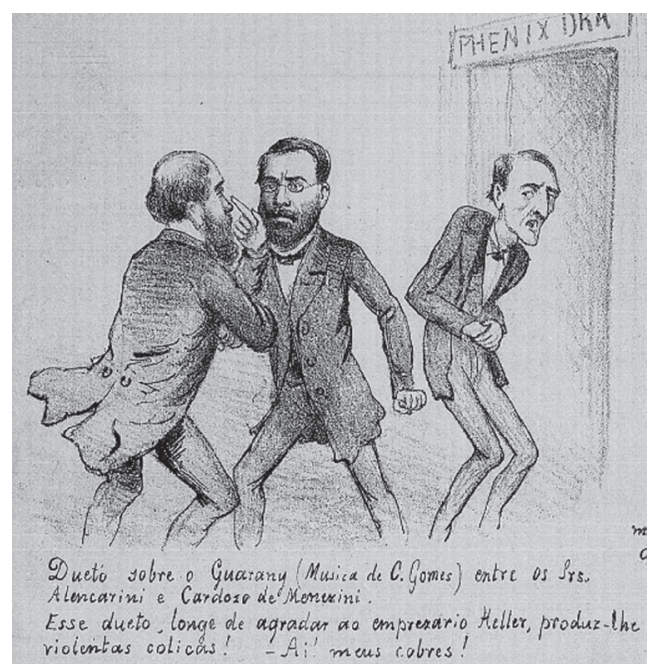

A primeira cláusula do acordo vetava a impressão do drama, enquanto a segunda dava exclusividade à companhia Fênix Dramática para montá-lo em duas séries de espetáculos, sem, contudo, exceder o número de 50 representações. A terceira e última cláusula estipulava que os anúncios deviam informar que a peça fora extraída do romance 0 Guarani, "com o consentimento do autor". Alencar endossou o acordo no dia 29 de abril e a peça finalmente estreou dias depois, a 9 de maio. Tudo transcorria bem, até que em agosto, depois da 31 ạ representação, o romancista impetrou um embargo judicial alegando quebra da segunda cláusula do acordo. Ele seguramente entendeu que a primeira série não deveria avançar para além da 25a representação. Novamente a polêmica alastrou-se pela imprensa. Dessa vez Alencar pelejou contra o Dr. José Antonio Fernandes Lima, advogado contratado por Jacinto Heller para tentar derrubar o embargo. Enfim, já em setembro, um segundo e derradeiro acordo foi celebrado entre o romancista e o empresário teatral cioso dos prejuízos (Faria, 1982: 84-97).

A Questão Guarani ofereceria as bases para o projeto de lei apresentado por Alencar no ano seguinte na Câmara dos Deputados. A começar pela defesa da propriedade literária como expressão do trabalho intelectual, conforme aparecia logo na primeira nota em que o romancista denunciava a "espoliação" de seu romance:

Consta-me que está anunciada a próxima representação de um drama extraído do meu romance O Guarani.

O empresário que anuncia não obteve licença minha, e, sem ela, creio que ninguém pode explorar o que me pertence pelo mais legítimo dos títulos de propriedade. 
Como autor, eu devia esperar que o Conservatório Dramático, instituído para regenerar a arte, não consentisse semelhante espoliação.

Pretendo pugnar pelo meu direito. Os tribunais decidirão se neste país do monopólio há ou não uma propriedade literária, e se aos teatros deste corte é lícito viver dos remendos de obras alheias, cerzidas em farsas e chocarrices. ${ }^{22}$

Em meio à discussão com o presidente do Conservatório Dramático, Alencar oferecia uma interpretação do artigo 261 do Código Criminal, distinguindo plágio e contrafação, o último classificado como furto. ${ }^{23}$ De acordo com A propriedade (1883), tratado jurídico de José de Alencar publicado após sua morte pelo jurista Antonio Joaquim Ribas, a defesa da propriedade como expressão do trabalho remontava ao Segundo Tratado do Governo Civil de Locke (Alencar, 1883: 126). Nesse sentido, é importante salientar que, além de romancista, dramaturgo, jornalista e político destacado, José de Alencar foi um jurisconsulto de renome, tendo ocupado o cargo de ministro da Justiça do gabinete conservador chefiado pelo visconde de Itaboraí, entre 1868 e 1870. Não surpreende, portanto, que a noção de propriedade intelectual apresentada em $A$ propriedade seja bastante elaborada, visivelmente fruto de densas elucubrações de seu autor.

Embora não tenha datado o manuscrito, o que torna difícil situá-lo com precisão em relação à Questão Guarani e ao projeto de lei de 1875, Antonio Joaquim Ribas afirmava na "Prefação" do livro que "aqui a palavra propriedade é empregada no seu sentido mais amplo, como sinônima de direito dos bens, e entre estes se compreendem as cousas incorpóreas", ou res quae tangi non possunt, ${ }^{24}$ segundo o axioma do jurista romano Gaio (Alencar, 1883: VI). Na medida em que Alencar denunciava a "tirania da cousa" e "o círculo de ferro da materialidade", ou seja, o descaso dos jurisconsultos com "uma propriedade nobre só porque não tem uma substância material", ele demonstrava que, de fato, aí residia o núcleo do reconhecimento da propriedade e, consequentemente, do trabalho intelectual (Alencar, 1883: 57; 62). Logo Alencar iniciava sua explanação tratando do direito dos inventores sobre seus inventos:

Quem não conhece e não consagra um culto de gratidão à Gutemberg, à Fullon, à Thomaz - Franklin, a tantos outros benfeitores da humanidade? Imaginemos que um homem de gênio como eles, havendo consumido em longas e profundas lucubrações sua existência, tendo exaurido as potências de sua alma e sacrificado o patrimônio de sua família, consegue enfim arrancar do desconhecido, do vácuo, uma invenção de alcance igual à da imprensa ou do vapor. Essa invenção tem dupla significação. Perante a moral exprime um dever, o dever da criatura

\footnotetext{
22 "O Guarani", Jornal do Commercio, 19 abr. 1874, p. 2.

23 "O Guarani", Jornal do Commercio, 21 abr. 1874, p. 2.

24 "Que não podem ser tocadas".
} 
para com o Criador que o iluminou e o elegeu instrumento do progresso humanitário. Perante o direito representa uma propriedade; representa a redenção da miséria, o futuro da prole, a reputação do nome (Alencar, 1883: 46).

Comentadores do Código Criminal do Império também sobrepunham propriedade intelectual e direito de patente ao escreverem sobre o artigo 261 (Souza, 1858: 96-97; Pessoa, 1877: 407). Os juristas partiam de uma leitura rigorosa do parágrafo 26 do artigo 179 da Constituição de 1824, que decretava que "os inventores terão a propriedade das suas descobertas, ou das suas produções. A Lei lhes assegurará um privilegio exclusivo temporário, ou Ihes remunerará em ressarcimento da perda, que hajam de sofrer pela vulgarização". ${ }^{25}$ Havia ainda a Lei de 28 de agosto de 1830, que concedia "privilégio ao que descobrir, inventar ou melhorar uma indústria útil e um prêmio ao que introduzir uma indústria estrangeira, e regula sua concessão". ${ }^{26}$ Portanto, é certo que os inventores estavam muito bem assistidos pelas leis do país. Não que Alencar desconhecesse tal fato, pelo contrário. Ele partia dos inventores de máquinas e melhoramentos úteis para chegar aos inventores, como ele, de obras literárias e artísticas. 0 elo entre ambos seria a imaterialidade do pensamento: "o invento não é uma cousa material, não tem corpo; por conseguinte não pode ser a sede de um direito tão nobre como o direito real: esse privilégio é reservado para a matéria vil e bruta. Dominium est jus in re corporale" 27 (Alencar, 1883: 48-49).

Por intermédio do trabalho, no entanto, o pensamento tornava-se tangível. Alencar então se reportava à longa história do direito, da controvérsia entre proculianos e sabinianos na Roma antiga sobre a propriedade de uma estátua até a defesa de Kant da propriedade dos editores sobre os exemplares de uma obra, para denunciar os prejuízos do "materialismo":

A legislação civil resignou-se a receber no seu grêmio, como um direito real, as produções do espírito; não para render culto à inteligência humana, a essa divindade de criatura divinae particulam aurae. Bem pouco se inquieta a jurisprudência com essas rugas. Foi revestindo uma forma física, palpável e sólida que o espírito obteve os foros do domínio (Alencar, 1883: 51-52).

Observando a Questão Guarani pela perspectiva de A propriedade, temos que Alencar defendia que ao se concretizar o pensamento em folhetim e livro este adquiria valor econômico e estatuto de propriedade:

\footnotetext{
${ }^{25}$ Constituição Política do Império do Brasil (de 25 de março de 1824). Disponível em: <http://www.planalto.gov.br/ccivil_03/Constituicao/Constituicao24.htm>. Acesso em: 27 fev. 2016.

${ }^{26}$ Disponível em: <http://www.planalto.gov.br/ccivil_03/leis/LIM/LIM-28-8-1830.htm>. Acesso em: 27 fev. 2016.

27 "O domínio é o direito na coisa corpórea".
} 
0 direito de propriedade, dissemos nós, tem sua sede no mundo material: essa é a sua essência, ele não pode existir senão na matéria. Em qualquer situação que o encontremos, seja qual for o estado abstrato em que se ache, ele tende necessariamente a realizar-se, a reduzir-se à utilidade e valor, embora torne a espiritualizar-se para a satisfação de qualquer necessidade moral. Assim os pensamentos que o escritor tira da sua inteligência são sem dúvida o que há de mais imaterial; por isso não podem constituir uma propriedade, senão quando tomam um preço venal; mas se o dono em vez de publicar um livro, contenta-se com o prazer de repetir aos seus ouvintes uma e outras vezes; esses pensamentos deixam de ser uma propriedade e tornam-se uma cousa comum, como o ar, a luz, etc. (Alencar, 1883: 267-268).

O romancista não cantou as façanhas do índio Peri contra os Aimorés como um aedo cego a vagar pelas ruas e praças do Rio de Janeiro. Conforme defendido em A propriedade, seus direitos sobre a obra provinham do trabalho intelectual, sendo garantidos pela materialização de seu pensamento no impresso. Porém, há ocasiões em que "o acaso, uma indiscrição, qualquer circunstância fortuita [põe] esse papel na mão de alguém de má fé, que se apropria do trabalho alheio, e comete um furto ignóbil e torpe". Furtam aos homens de engenho "não só a ideia, mas o pão amassado com o suor - aufert in sudore panem. E que suor? 0 mais acerbo e o mais cruel, o suor da inteligência!" (Alencar, 1883: 47).

\section{À gUISA DE CONCLUSÃo: PropriedAdE LITERÁRIA E TENSÕES CULTURAIS NA CORTE IMPERIAL}

$\mathrm{E}$ m dezembro de 1877, durante o concorridíssimo funeral de José de Alencar, foi dado um passo importante no sentido da organização dos homens de letras da Corte. Capitaneados por Francisco Otaviano, um grupo de escritores decidiu então fundar uma associação. ${ }^{28}$ Ultrapassaria os objetivos e limites deste artigo analisar os desdobramentos do associativismo literário no Rio. No entanto, paradoxalmente, José de Alencar não encontrou apoiadores na imprensa em sua cruzada em defesa da propriedade literária e do trabalho intelectual enquanto viveu. Ao contrário, as caricaturas do autor publicadas durante a Questão Guarani revelam as tensões culturais em torno da causa por ele defendida. ${ }^{29}$ Assim, ao folhearmos as revistas ilustradas que cobriram a polêmica percebemos que o autor pode ter enfrentado parte substancial da imprensa que, por seu turno, apoiava os empresários teatrais do Rio de Janeiro.

28 "Noticiário", Diário do Rio de Janeiro, 15 dez. 1877, p. 1.

${ }^{29}$ Neste ponto, E. P. Thompson (1998: 17) lembra que cultura "é uma arena de elementos conflitivos". 
A série de caricaturas publicadas em $A$ Vida Fluminense retratava o romancista em diferentes situações cômicas. A parte superior do conjunto representava Alencar defendendo a posse do título de seu romance. No primeiro desenho ele aparece alçado em um poste tentando borrar o letreiro do café 0 Guarani, estabelecimento de Diogo Thomaz Pereira que ficava na Rua do Teatro, no $19 .{ }^{30}$ O segundo mostrava Alencar às turras com o Dr. Soeiro Guarani, médico que atendia no sobrado da esquina da Rua das Flores com a Rua do Conde d'Eu. ${ }^{31}$

Figura 4: A Vida Fluminense, 2 mai. 1874, p. 1807.

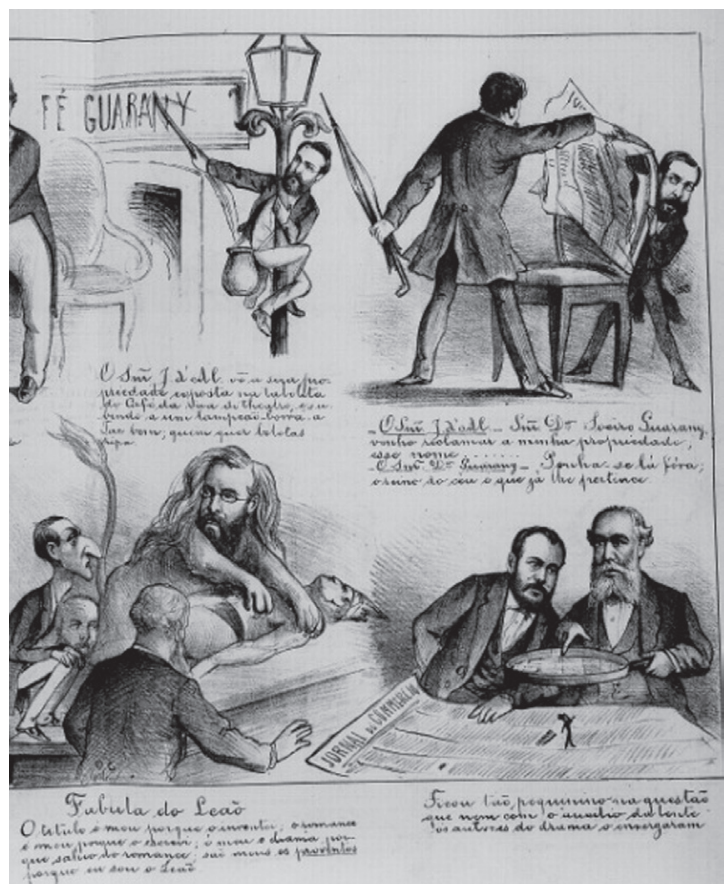

Do ponto de vista de um morador da Corte Imperial, a referencialidade dos desenhos era precisa e as legendas que os acompanhavam inflacionavam o escárnio. Logo abaixo do primeiro desenho lia-se: "O Sr. J. d'Al. vê a sua propriedade exposta na tabuleta do café da Rua do Teatro e, subindo em um lampião, borra-a. Faz bem, quem quer bolotas trepa". A legenda do segundo desenho que representava um Alencar propositalmente diminuído, escondendo-se do médico e seu guarda-chuva atrás de uma cadeira, trazia um diálogo: "0

\footnotetext{
30 "Anúncios: À praça", D. Pedro II, 7 jan. 1874, p. 4.

31 "O Dr. Soeiro Guarani", Jornal do Commercio, 18 mai. 1873, p. 5.
} 
Sr. J. d'Al. - Sr. Dr. Soeiro Guarani venho reclamar a minha propriedade, esse nome.../ O Sr. Dr. Guarani - Ponha-se lá fora; o reino do céu é que lhe pertence".

A terceira caricatura, "Fábula do Leão", trazia um Alencar travestido de rei das selvas defendendo seu Guarani do empresário Heller, de cócoras, bem como dos adaptadores do romance. A legenda diz: "O título é meu porque o inventei; o romance é meu porque o escrevi; é meu o drama porque saiu do romance; são meus os proventos porque que sou o leão". 0 sentido da piada mudava, pois surgia um Alencar avarento, cioso dos lucros auferidos pela adaptação de seu romance. Por outro lado, se levarmos em conta uma das célebres personagens alencarinas, o frívolo Horácio de Almeida do romance A pata da gazela (1870: 10), "leão" podia não ser um epíteto muito elogioso. A quarta caricatura tomava o partido dos adaptadores do romance para o teatro. Com uma lupa em mão Visconti Coaraci mostrava a Pereira da Silva um Alencarzinho minúsculo a esbravejar das colunas do Jornal do Commercio. 0 tamanho do romancista seguramente correspondia às dimensões que o caricaturista atribuía às suas admoestações sobre propriedade, espoliação e trabalho intelectual. A legenda completava o quadro: "Ficou tão pequenino na questão que nem com o auxílio da lente os autores do drama o enxergaram".

A imagem de um Alencar sovina reapareceu em outra caricatura publicada no mesmo dia na revista 0 Mosquito (Figura 5). Retratando o primeiro acordo celebrado entre 0 romancista e o empresário teatral, vemos Heller dando de comer a um famélico Alencar. Se repararmos bem, a iguaria servida eram moedas, e o desenho trazia a seguinte legenda: "O autor e o empresário do Guarani entendem-se agora às mil maravilhas. A questão era de fome".

Figura 5: 0 Mosquito, 2 mai. 1874, p. 4.

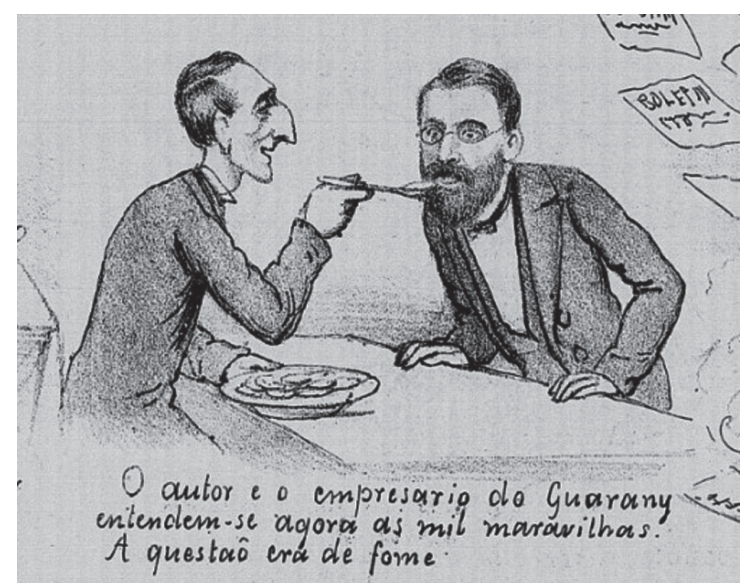


Porém, mais incisiva neste nesse ponto foi a capa da revista Mephistópheles, publicada pouco antes do desfecho da Questão Guarani. No desenho, Mephisto, personagem que representava o periódico, punia um raquítico Alencar atado a um pelourinho que trazia no alto a tabuleta: "Quasímodo da Literatura". A legenda do desenho dizia: "Exposto à visão pública tacanho e raquítico não haverá Esmeralda que te dê uma gaita de razão e te livre do ridículo em que caíste".

Figura 6: 0 Mephistópheles, 15 ago. 1874, capa.

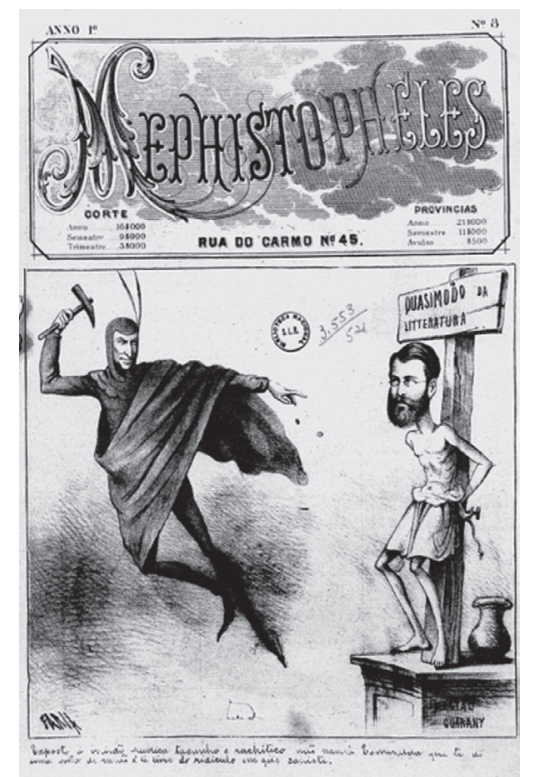

Figura 7: Frontispício do romance Notre Dame de Paris (1831).

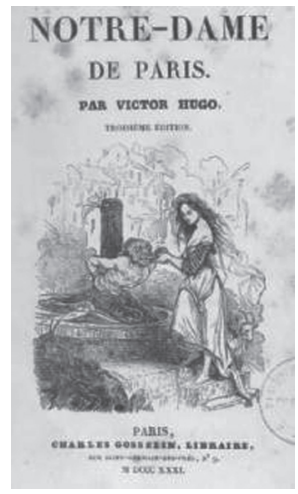

Figura 8: Ilustração do cap. VI, parte VI do romance Notre Dame de Paris (1865).

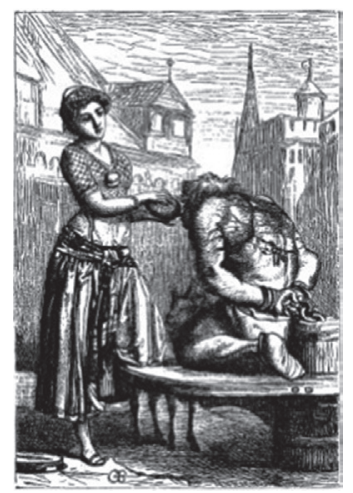


A cena aludia ao capítulo "Uma lágrima por uma gota d'água" do romance Notre Dame de Paris de Victor Hugo. Edições ilustradas da obra poderiam ter inspirado a composição do Alencar-Quasímodo, alegoria carregada de tons pejorativos (Figuras 7 e 8). Para parte da imprensa que tomara partido do "capitalista" Jacinto Heller, Alencar teria desempenhado o papel de "papa dos bufos", merecendo, de modo semelhante ao sineiro da catedral parisiense, ser chicoteado e ridicularizado em praça pública. Por outro lado, deve-se considerar que essas revistas se aproximavam do Partido Liberal, o que aprofundava ainda mais o abismo entre elas e o conservador José de Alencar. ${ }^{32}$ Em todo caso, as caricaturas fomentavam as disputas em torno das diferentes concepções de propriedade literária e trabalho intelectual no Rio de Janeiro, as quais seriam parcialmente resolvidas com a promulgação da Lei n. 496 de 1 de agosto de 1898.

\section{FONTES (IMPRENSA, MANUSCRITOS, LEIS E DECRETOS)}

A Vida Fluminense, 1868; 1874.

Correio da Tarde, 1856.

D. Pedro II, 1874.

Jornal do Commercio, 1857; 1858; 1873; 1874.

Marmota Fluminense, 1855.

O Mephistópheles, 1874.

O Mosquito, 1874.

Revista Brasileira, T. VI, out.-dez. 1880.

Revista Popular, T. XII, 1861.

Semana Illustrada, 1861.

ASSIS, Machado de. Contrato celebrado entre Joaquim Maria Machado de Assis e o editor B. L. Garnier para a 1a edição da obra Helena do Vale. Consta o recibo da importância paga por esse contrato. Rio de Janeiro, 29 abr. 1876. Biblioteca Nacional do Rio de Janeiro, Manuscritos, I-7, 9, 4.

Constituição Política do Império do Brasil (de 25 de março de 1824). Disponível em: <http://www.planalto. gov.br/ccivil_03/Constituicao/Constituicao24.htm>. Acesso em: 27 fev. 2016.

Lei de 28 de agosto de 1830. Disponível em: <http://www.planalto.gov.br/ccivil_03/leis/LIM/LIM-28-8-1830. htm>. Acesso em: 27 fev. 2016.

\footnotetext{
32 Ver, por exemplo: "Cidadãos eleitores", 0 Mosquito, 23 mar. 1872, p. 2, e "Tempo perdido", o Mephitópheles, n. 74 , p. 6.
} 
Anais da Câmara dos Deputados, Sessão de 14 de agosto de 1856.

Anais da Câmara dos Deputados, Sessão de 21 de agosto de 1857.

Anais da Câmara dos Deputados, Sessão de 30 de maio de 1858.

Anais da Câmara dos Deputados, Sessão de 7 de julho de 1875.

\section{REFERÊNCIAS BIBLIOGRÁFICAS}

ALENCAR, José de. O demônio familiar: comédia em quatro atos. Rio de Janeiro: Soares e Irmão, 1858.

—. As asas de um anjo: comédia. Rio de Janeiro: Soares e Irmão, 1860.

—. Mãe: drama em quatro atos. Rio de Janeiro: Tip. de F. de Paula Brito, 1862.

—. A pata da gazela: romance brasileiro. Rio de Janeiro: B. L. Garnier, 1870.

—. A propriedade. Rio de Janeiro: B. L. Garnier, 1883.

AUGUSTI, Valéria. Os fundamentos da propriedade literária por José de Alencar. Todas as letras, v. 14, n. 1, 2012.

BILAC, Olavo. Poesias: edição definitiva. Rio de Janeiro; Paris: H. Garnier, 1902.

FARIA, João Roberto. O teatro realista no Brasil (1855-1865). São Paulo: Perspectiva, 1993.

. José de Alencar: a polêmica em torno da adaptação teatral de O Guarani. Letras, Curitiba, n. 31, 1982.

GODOI, Rodrigo Camargo de. Um editor no Império: Francisco de Paula Brito, 1809-1861. São Paulo: Edusp, Fapesp, 2016.

GRAND-CARTERET, John. Zola en images. Paris: Juven, 1907.

GUIMARÃES, Aprígio Justiniano da Silva. Propriedade literária: histórico e sustentação de um projeto a respeito. Recife: Tipografia Acadêmica, 1859.

HUGO, Victor. Notre Dame de Paris. Paris: C. Gosselin, 1831.

—_. Les contemplations. Tome I. Paris: Michel Lévy Frères; J. Hetzel; Pagnerre, 1856.

—. Notre Dame de Paris. Illustrée de Soixante-Dix Dessins par Brion. Paris: J. Hetzel et A. Lacroix, 1865.

KUNZLE, David. Goethe and Caricature: from Hogarth to Töpffer. Journal of the Warburg and Courtauld Institutes, vol. 48, 1985, pp. 164-188.

MENCARELLI, Fernando Antonio. A voz e a partitura: teatro musical, indústria e diversidade cultural no Rio de Janeiro (1868-1908). Tese (Doutorado em História Social) IFCH, Unicamp, Campinas, 2003.

MOLLIER, Jean-Yves. A leitura e seu público no mundo contemporâneo: ensaios sobre história cultural. Trad. Elisa Nazarian. Belo Horizonte: Autêntica Editora, 2007.

PESSOA, Vicente Alves de Paula. Código Criminal do Império do Brasil anotado com leis, decretos, jurisprudência dos tribunais do país e avisos do governo até o fim de 1876. Rio de Janeiro: Livraria Popular, 1877. 
SANDRAS-FRAYSSE, Agnès. Clins d'œil savants aux critiques littéraires: les caricatures de Zola. In: LE MEN, Ségolène (dir.). L'art de la caricature. Nanterre: Presse Universitarie de Paris Ouest, 2014.

SLENES, Robert W. Grandeza ou decadência? 0 mercado de escravos e a economia cafeeira da Província do Rio de Janeiro, 1850-1888. In: COSTA, Iraci Del Nero da. Brasil: História Econômica e Demográfica. São Paulo: Instituto de Pesquisas Econômicas, 1986.

SOUZA, Braz Florentino Henriques de. Código criminal do Império do Brasil: anotado com as leis, decretos, avisos e portarias publicados desde a sua data até o presente. Recife: Tipografia Universal, 1858.

SOUZA, Silvia Cristina Martins de. As noites do Ginásio: teatro e tensões culturais na Corte (1832-1868). Campinas: Editora da Unicamp; Cecult, 2002.

THOMPSON, E. P. Costumes em comum: estudos sobre a cultura popular tradicional. São Paulo: Companhia das Letras, 1998. 